\title{
Association between genetic polymorphism of growth-hormone-releasing hormone and the yield, chemical composition and technological parameters of cow milk (Brief Report)
}

\section{Der Zusammenhang zwischen dem genetischen Polymorphismus von Somatoliberin und der Milchleistung, Milchzusammensetzung und den technologischen Milchparametern bei Kühen (Brief Report)}

\author{
Ewa Czerniawska-Piątkowska', Małgorzata Szewczuk ${ }^{1}$ and Sławomir Zych² \\ 'Laboratory of Molecular Cytogenetics, Department of Ruminant Science, The West Pomeranian University of \\ Technology, Szczecin, Poland, ${ }^{2}$ Laboratory of Vet Diagnostic »LaboWet«, Szczecin, Poland
}

\section{Background}

Somatoliberin or growth-hormone-releasing hormone (GHRH) belongs to a group of hypothalamic hormones. It induces an increase in the concentration of endogenous growth hormone in the blood serum of cattle (Løvendahl et al. 1991), increasing mean and pulsatile liberation of somatotropin and thus affecting indirectly an increase in the milk productivity of cows (Dahl et al. 1993). The study aimed at searching for associations between the variants of the GHRH/Haelll polymorphism, described for the first time by Moody et al. (1995), and production traits in the examined herds and comparing the technological usefulness of milk obtained from cows with different GHRH genotypes. According to Szewczuk et al. (2008), above mentioned polymorphism is the transversion $A \rightarrow C$ located at the position $A 44 C$ within initial part of intron 2 (GenBank acc. no. EF210074).

\section{Procedures}

Examinations were carried out on 1188 Holstein-Friesian cows of Black-and-White strain kept in two farms in the Lubusz Province (farm A) and the Western Pomeranian Province (farm B). DNA for examination was isolated from the whole peripheral blood collected to test-tubes with K3EDTA using MasterPure Genomic DNA Purification Kit provided by Epicentre Technologies. The genotypes of the GHRH/Haelll polymorphism were assayed with polymerase chain reaction - restriction fragment length polymorphism (PCR-RFLP). The reaction was performed in the Biometra Tpersonal thermocycler. The following primers designed by Dybus et al. (2003) were applied: GHRHF 5' ttc cca agc ctc tca ggt aa 3' and GHRHR $5^{\prime}$ gcg tac cgt gga atc cta gt $3^{\prime}\left(\mathrm{T}_{\mathrm{a}}=60^{\circ} \mathrm{C}\right)$. The obtained DNA fragments of $297 \mathrm{bp}$ were digested with 4 units of restriction enzyme Haelll ( $g \mathrm{~d} \downarrow \mathrm{cc}$; Fermentas). Digestion products were separated by electrophoresis in $2 \%$ agarose gel with ethidium bromide and visualized under UV light $(312 \mathrm{~nm})$ in a Vilber Lourmat transilluminator. The analysis of milk performance was based on the data obtained from the official milk recordings. Additionally, 
milk samples from each farm ( $\mathrm{n}=69$ for $G H R H A A, A B, B B$ ) were taken, in which the following was determined: chemical composition (fat, protein, lactose) using Milcos-Scan 104 device, active acidity $(\mathrm{pH})$, potential acidity using titration method $(\mathrm{OSH})$ and flocculation time (s) using rennet method. The obtained results were analysed statistically using the Duncan multiple range test by means of Statistica 7.1 PL software.

\section{Results}

In both herds, two alleles $\left(G H R H^{A}\right.$ and $\left.G H R H^{B}\right)$ and three genotypes ( $A A$ with bands of 242 bp and $55 \mathrm{bp} ; A B$ with bands of $242 \mathrm{bp}, 194 \mathrm{bp}, 55 \mathrm{bp}$ and $48 \mathrm{bp}$; $B B$ with bands of 194 $\mathrm{bp}, 55 \mathrm{bp}$ and $48 \mathrm{bp}$ ) were identified. The $B B$ genotype was observed most frequently (frequencies 0.631 and 0.704 for herds $A$ and $B$, respectively) and the $A A$ genotype least frequently ( 0.042 and 0.054 , respectively). The frequencies of the heterozygous genotype were 0.327 and 0.242 , respectively. The frequency of the $G H R H^{A}$ allele was higher in herd A (0.206) than in herd B (0.175). Dybus \& Grzesiak (2006) found equally low frequency of the $G H R H^{A}$ allele (0.211) in the population of Polish Black-and-White cattle. In Polish Redand-White cattle, Kmieć et al. (2007) estimated the frequency of the $G H R H^{A}$ allele at 0.281 . Moody et al. (1995) reported a significantly higher frequency of the $G H R H^{A}$ allele in Angus cattle (0.700) and a lower one in Hereford cattle (0.070). In the present study, cows with the GHRH AA genotype were characterized by the highest milk yield in both farms. Significant differences $(P \leq 0.05$ and $P \leq 0.01)$ were found within a given herd and between the analysed herds. Milk fat and milk protein contents were the highest in herd A for animals with the GHRH AA genotype (4.26\% and $3.43 \%$, respectively). Association study performed by Kmieć et al. (2007) revealed statistically higher values for the all analyzed milk production traits in cows with $A A$ genotype $(P \leq 0.05)$. Dybus \& Grzesiak (2006) also found that individuals with one or two $G H R H^{A}$ alleles might produce milk of a higher fat percentage (although not statistically significant). However, in the study performed by Szewczuk et al. (2008), the BB-genotype cows were characterized by a higher fat yield and percentage $(P \leq 0.01)$. In the present study, the milk of cows from herd $A$ was characterized by significantly $(P \leq 0.01$ and $P \leq 0.05)$ better physico-chemical and technological traits for cheese production compared to the milk of cows from herd $\mathrm{B}$. The highest content of casein (2.85\%) was found in the milk of the $A B$ heterozygotes in herd $A$ and in the milk of the $A A$ homozygotes in herd $B(2.79 \%)$. The milk of cows with $A A$ and $B B$ genotypes in farm $A$ was characterized by the same content of whey protein $(0.53 \%)$, whereas the shortest clotting capability time $(286 \mathrm{~s})$ and the highest lactose content (4.92\%) were found in the milk of the $A B$ heterozygotes. There are no other literature data concerning the association between technological usefulness of milk and the GHRH/ Haelll polymorphism.

\section{References}

Dahl GE, Chapin LT, Moseley WM, Tucker HA (1993) Galactopoietic effects of recombinant somatotropin and growth hormone- releasing factor in dairy cows. J Dairy Sci 76, 1550-1557

Dybus A, Kmieć M, Sobek Z, Pietrzak W, Wiśniewski B (2003) Associations between polymorphisms of growth hormone releasing hormone (GHRH) and pituitary transcription factor 1 (PIT1) genes and production traits of Limousine cattle. Arch Tierz 46, 527-534 
Dybus A, Grzesiak W (2006) GHRH/Haelll gene polymorphism and its associations with milk production traits in Polish Black-and-White cattle (short communication), Arch Tierz 49, 434-438

Kmieć M, Kowalewska-Łuczak I, Kulig H, Terman A, Wierzbicki H, Lepczyński A (2007) Associations between GHRH/Haelll restriction polymorphism and Milk production traits In a herd of dairy cattle. J Anim Vet Adv $6,1298-1303$

Løvendahl P, Woolliams JA, Sinnett-Smith PA (1991) Response of growth hormone to various doses of growth hormone releasing factor and thyrotropin releasing hormone administered separately and in combination to dairy calves. Can J Anim Sci 71, 1045

Moody DE, Pomp D, Barendse W (1995) Restriction fragment length polymorphism in amplification products of the bovine growth-hormone-releasing hormone gene. J Anim Sci 73, 3789

Szewczuk M, Zych S, Chaberski R (2008) Effect of growth hormone-releasing hormone gene polymorphism (GHRH/HaellI) on milk performance in Polish Holstein-Friesian cows. Acta Univ Agric Silvic Mendel Brun 4, 177-181

Received 1 March 2010, accepted 22 February 2011.

Corresponding author:

Ewa Czerniawska-Piątkowska

email: ewa.czerniawska-piatkowska@zut.edu.pl

Laboratory of Molecular Cytogenetics, Department of Ruminant Science, The West Pomeranian University of Technology, Judyma 10, 71-460 Szczecin, Poland 